$10-15-2020$

\title{
Characteristics of brokers in relation to the migration of girls and young women in Ethiopia
}

Annabel Erulkar

Follow this and additional works at: https://knowledgecommons.popcouncil.org/departments_sbsr-pgy

Part of the Migration Studies Commons

How does access to this work benefit you? Let us know!

\section{Recommended Citation}

Erulkar, Annabel. 2020. "Characteristics of brokers in relation to the migration of girls and young women in Ethiopia," brief. Addis Ababa: Population Council. 


\section{CHARACTERISTICS OF BROKERS IN RELATION TO THE MIGRATION OF GIRLS AND YOUNG WOMEN IN ETHIOPIA}

\section{ANNABEL ERULKAR}

Contrary to popular belief, the majority of internal, rural-urban migrants in Ethiopia are female and not male. According to research by The World Bank, among rural migrants to Addis Ababa, 69 percent were female; likewise, 56 percent of rural migrants to other urban areas of Ethiopia were female. Migrants tended to be adolescents or young adults, with migrants to Addis Ababa being, on average, 22 years old. The World Bank study highlighted the difficulty in transitioning to paid work once reaching one's destination, especially for females.

Brokers (known as delalas in Amharic) are intermediaries or "go-betweens" that facilitate transactions across a number of sectors in Ethiopia, such as purchase or rental of housing, vehicles, and other services such as insurance. Brokers are also active in job placement, connecting employers with employees, and frequently supplying households, restaurants, and bars with domestic workers, waitresses, or bar staff. Newly arriving migrants frequently turn to brokers to help place them into jobs, especially when they migrate without a job already in place.

In Ethiopia, brokers are required to register with the Ministry of Labour and Social Affairs which includes reporting income and paying taxes. However, many do not register and remain unlicensed and work illegally. Those who possess licenses may work from offices and employ others in the business. Unlicensed brokers typically do not have offices and operate without a fixed address, simply staying in places where brokers congregate or running their business over a mobile phone. $^{2}$

Therefore, the role of brokers is an integral part of the migration experience of many girls and young women, and their activities and actions may have a significant impact on the well-being of migrant females. In addition to offering job placements to migrants, brokers may be mechanisms for other sources of support and advice for girls who are new to the city, or they may represent a source of risk for girls, including sexual exploitation.
This research brief focuses on brokers in Ethiopia-both licensed and unlicensedwho place migrating girls into jobs such as domestic work, waitressing, and commercial sex work. We examine the characteristics of brokers, their contacts, ways of working, and how brokers both support and harm migrant girls.

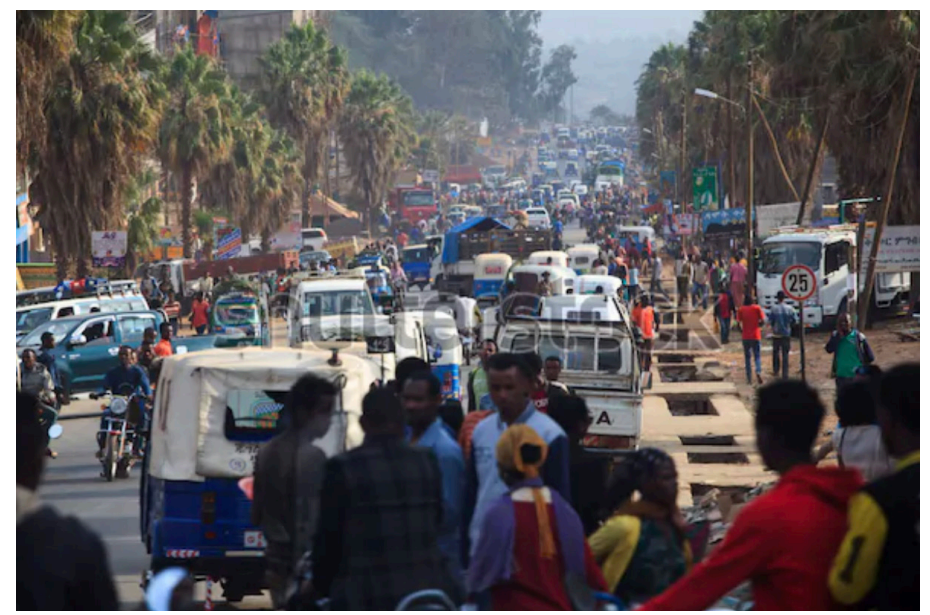

\section{METHODOLOGY}

In 2016, the Population Council undertook largescale research among out-of-school migrant girls and young women in Ethiopia. The study took place in 10 Ethiopian cities: Adama, Addis Ababa, Dessie, Dire Dawa, Gendawuha, Gondar, Harar, Mekelle, Metema, and Shashamene. The study used mixed methods: an initial qualitative research phase, followed by a quantitative survey. In each city, locations where a large number of rural-urban migrants are located were identified. In these sites, an initial household survey was undertaken to identify girls and young women who were eligible for the survey. Ultimately, migrant girls and young women aged 15 to 24 were selected for the study. Previous research 
revealed that a significant proportion of commercial sex workers were migrants. ${ }^{3}$ As a hidden population not readily sampled in household surveys, commercial sex workers (among those who self-identified as such) aged 18 to 24 were also recruited using snowball sampling. In the study, 4,540 out-of-school female migrants were interviewed.

In addition, we interviewed 20 brokers in the qualitative study and 270 brokers in the quantitative survey.

Respondents were selected using snowball sampling. To facilitate entry into locations where brokers operate, trained interviewers spent time in places where brokers were known to work, especially in the vicinity of bus stations-which are the arriving points for migrant girls in cities-as well as market areas. Once interviewers became familiar with the people who frequented those locations, they were able to identify the brokers who operated in those areas. Brokers were then approached for interview and informed consent was obtained. In the qualitative survey, interviews were tape recorded and respondents were interviewed over several visits. The approach of multiple subsequent interviews was utilized because respondents typically become progressively more candid with the interviewer. In the quantitative survey, 30 brokers were interviewed in each cityexcept Gendawuha and Metema, where 15 brokers were interviewed in each city. Among those interviewed in the quantitative study, 165 were unlicensed and 105 were licensed. Only four brokers were female (two licensed and two unlicensed). To our knowledge, this is the first survey of job placement brokers in Ethiopia, which provides new information about patterns of practice among this profession.

\section{RESULTS}

\section{CHARACTERISTICS OF BROKERS}

This research brief focuses on the results from brokers in the study. ${ }^{4}$ On average, brokers were roughly 32 years old, ranging from 21 to 55 years of age. There was no significant difference in the age of licensed and unlicensed brokers, although unlicensed brokers tended to be younger and more likely to be in their 20s, compared to licensed brokers. Likewise, there was no significant difference in migrant status or educational attainment among licensed and unlicensed brokers, who possessed an average of 8.5 years of education. Seventy-nine percent of brokers completed primary school, but only 11 percent completed senior secondary school (12 years education). Very few brokers (3 percent) had no education.
TABLE 1: Characteristics of brokers, by licensing status

\begin{tabular}{|c|c|c|c|}
\hline & $\begin{array}{l}\text { Unlicensed } \\
\quad(n=165)\end{array}$ & $\begin{array}{l}\text { Licensed } \\
(n=105)\end{array}$ & $\begin{array}{c}\text { All } \\
(n=270)\end{array}$ \\
\hline \multicolumn{4}{|l|}{ Age category (NS) } \\
\hline $20-29$ & 44.2 & 37.1 & 41.5 \\
\hline $30-39$ & 44.2 & 49.5 & 46.3 \\
\hline $40-49$ & 10.9 & 9.5 & 10.4 \\
\hline $50+$ & 0.6 & 3.8 & 1.9 \\
\hline Migrant to the area (NS) & 69.1 & 72.4 & 70.4 \\
\hline \multicolumn{4}{|c|}{ Educational attainment (NS) } \\
\hline None & 3.0 & 1.9 & 2.6 \\
\hline 1 to 4 years & 5.5 & 2.9 & 4.4 \\
\hline 5 to 8 years & 35.2 & 37.1 & 35.9 \\
\hline $9+$ years & 56.4 & 58.1 & 57.0 \\
\hline
\end{tabular}

Because the brokers we interviewed mainly supported girls and young women in finding work, we sought to understand their attitudes toward selected gender issues (Table 2). Respondents were read four statements related to the abilities of girls versus boys in school. Overall a considerable percentage of brokers held negative views on the abilities of girls. At the same time, on each of the four statements, unlicensed brokers were significantly more likely to hold negative views regarding girls' scholastic abilities, including considering them not to be as good as boys in school (39 percent of unlicensed brokers versus 20 percent of licensed brokers) and considering them to be lazy in school (35 percent of licensed brokers versus 25 percent of licensed brokers).

\section{PATTERNS OF WORK AMONG BROKERS}

Licensed and unlicensed brokers have very similar incomes and working hours, though their methods of working differ considerably (Table 3). On average, licensed brokers reported an average of 55 hours of

TABLE 2: Attitudes of brokers on selected gender issues, by licensing status

\begin{tabular}{|c|c|c|}
\hline $\begin{array}{l}\text { Percent agreeing with the } \\
\text { statement }\end{array}$ & $\begin{array}{l}\text { Unlicensed } \\
\quad(n=165)\end{array}$ & $\begin{array}{l}\text { Licensed } \\
(\mathrm{n}=105)\end{array}$ \\
\hline $\begin{array}{l}\text { Girls are not as good as boys in } \\
\text { school** }^{\star *}\end{array}$ & 39.4 & 20.0 \\
\hline $\begin{array}{l}\text { Boys should be sent to school } \\
\text { before girls* }\end{array}$ & 23.0 & 11.4 \\
\hline $\begin{array}{l}\text { Boys are better at math than } \\
\text { girls**}\end{array}$ & 41.2 & 24.8 \\
\hline 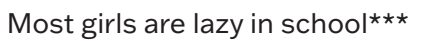 & 35.2 & 10.5 \\
\hline
\end{tabular}

Differences between groups significant at ${ }^{*} p<0.05^{* *} p<0.01{ }^{* \star *} p<0.001$ 
"I also buy them food if they are hungry

and if they don't have any money. I know

how it is to be hungry. At least I can buy

them shiro to share."-Licensed broker work per week with an income of 2,003 Ethiopian birr per month (approximately US\$91). ${ }^{5}$ Similarly, brokers who were not licensed reported an average of 52 weekly working hours with an income of 1,866 Ethiopian birr per month (approximately US\$85).

In contrast, the location of work, recruitment methods, and extent of networks differed between those who were licensed versus those who were not licensed. The vast majority of licensed brokers worked from an office they rented for the business (86 percent), whereas unlicensed brokers tended to work in more informal arrangements and in a range of settings including in open air locations (63 percent), at bus terminals (26 percent), and from their homes (26 percent). Almost all licensed brokers reported receiving clients in their offices (98 percent), among other places. However, unlicensed brokers were mainly contacted by mobile phone (93 percent), or through community members connecting them with clients (68 percent). One broker described the network of people connecting migrants and brokers and the importance of the bus station as a center for those connections:

For example, there are children who are just sitting around the bus station... There are various females arriving. They may have had their luggage stolen; they may be coming in search of work. There are also those who come because their families hear there are jobs that the girls could do here. When they get to the bus station, they [children] bring them to us when they ask to meet brokers. They make them meet us. There are people who sit and wait for them there lat the bus station]. When they bring them meet us, you link her with a job... You share your phone number with her. After that, she will call you on phone. She calls you maybe after 1 or 2 months in case she wants to change her place of work. Do you know the main source of all this? It is in the bus station.-Unlicensed broker

TABLE 3: Patterns of broker work among licensed and unlicensed brokers

\begin{tabular}{|c|c|c|c|}
\hline & Licensed $(n=105)$ & Unlicensed (n=165) & All brokers $(n=270)$ \\
\hline Average number of working hours per week & 55 & 52 & 53 \\
\hline Average earnings from brokering in the last month ${ }^{1}$ & ETB 2,003 (USD\$91) & ETB 1,866 (USD\$85) & ETB 1,919 (USD\$87) \\
\hline \multicolumn{4}{|l|}{ Location where most brokering is conducted ${ }^{2}$} \\
\hline Office broker rented for the business ${ }^{\star \star \star}$ & 85.7 & 13.3 & 41.5 \\
\hline Open location / in the neighborhood ${ }^{\star \star \star}$ & 1.9 & 63.0 & 39.3 \\
\hline 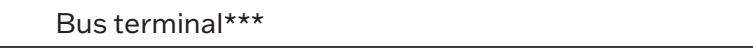 & 8.6 & 26.1 & 19.3 \\
\hline From broker's home $e^{\star \star \star}$ & 7.6 & 26.1 & 18.9 \\
\hline Office belonging to another business ${ }^{\star \star \star}$ & 4.8 & 21.8 & 15.2 \\
\hline Taxi terminal ${ }^{\star \star \star}$ & 0.0 & 15.8 & 9.6 \\
\hline \multicolumn{4}{|l|}{ How brokers are contacted by people looking for jobs ${ }^{1}$} \\
\hline Contacted by mobile phone ${ }^{\star \star \star}$ & 65.4 & 93.3 & 82.5 \\
\hline Clients come to broker's office/place of work ${ }^{\star \star \star}$ & 98.1 & 43.0 & 64.3 \\
\hline Brought by community members ${ }^{\star \star \star}$ & 25.0 & 67.9 & 51.3 \\
\hline Locate people at bus stages or taxi stops ${ }^{\star \star \star}$ & 10.6 & 37.6 & 27.1 \\
\hline Brought by taxi or bajaj drivers ${ }^{\star \star}$ & 8.7 & 21.8 & 16.7 \\
\hline \multicolumn{4}{|l|}{ Broker networks } \\
\hline Collaborate/network with brokers in the same city** & 52.4 & 71.5 & 64.1 \\
\hline Collaborate/network with brokers in other cities* & 12.4 & 24.2 & 19.6 \\
\hline Collaborate/network with brokers in rural areas ${ }^{\star \star}$ & 3.8 & 15.2 & 10.7 \\
\hline $\begin{array}{l}\text { Ever received requests from clients before they } \\
\text { migrate }\end{array}$ & 15.4 & 31.1 & 25.0 \\
\hline Ever traveled to other locations to bring clients & 2.9 & 6.1 & 4.9 \\
\hline
\end{tabular}

Differences between groups significant at ${ }^{\star} \mathrm{p}<0.05{ }^{* \star} \mathrm{p}<0.01{ }^{\star * *} \mathrm{p}<0.001 ;{ }^{1} 2016$ approx. exchange $\$ 1-\mathrm{ETB} 22 ;{ }^{2} \mathrm{Percentages}$ may sum to over 100 as more than one response was allowed. 
Compared with licensed brokers, unlicensed brokers reported more extensive broker contacts in other cities and other locations. Twenty-four percent of unlicensed brokers worked with brokers in other cities compared to 12 percent of licensed brokers; 15 percent of unlicensed brokers worked with brokers in rural areas compared to 4 percent of licensed brokers. Finally, 6 percent of unlicensed brokers and 2 percent of licensed brokers reported ever having traveled to another location to accompany clients/workers.

\section{JOB PLACEMENTS}

The most common type of job placement reported by brokers were waitresses (94 percent), domestic workers (80 percent), cooks (80 percent), and dishwashers (67 percent) (Table 4). Patterns of job placements varied among licensed and unlicensed brokers. Licensed brokers were significantly more likely to have made placements for waitresses, cooks, and dishwashers, while unlicensed brokers were more likely to place domestic

TABLE 4: Percent of brokers making job placement in the last three months, by type of job and licensing status

\begin{tabular}{|c|c|c|c|}
\hline & $\begin{array}{c}\text { Licensed } \\
(n=105)\end{array}$ & $\begin{array}{l}\text { Unlicensed } \\
\qquad(n=165)\end{array}$ & $\begin{array}{l}\text { All brokers } \\
(\mathrm{n}=270)\end{array}$ \\
\hline Waitress ${ }^{\star \star}$ & 99.0 & 90.3 & 93.7 \\
\hline Domestic servant* & 73.3 & 84.8 & 80.4 \\
\hline Cook ${ }^{\star \star \star}$ & 96.2 & 69.7 & 80.0 \\
\hline Dishwasher ${ }^{\star \star \star}$ & 87.6 & 54.5 & 67.4 \\
\hline Bar maid* & 27.6 & 41.8 & 36.3 \\
\hline Cashier** & 43.8 & 26.1 & 33.0 \\
\hline Sex worker & 3.8 & 9.1 & 7.0 \\
\hline
\end{tabular}

Differences between groups significant at ${ }^{*} p<0.05^{* *} p<0.01{ }^{\star * *} p<0.001$;
TABLE 5: Percent of brokers giving other forms of support to girls, by type of support and licensing status

\begin{tabular}{|c|c|c|c|}
\hline & $\begin{array}{l}\text { Licensed } \\
(n=105)\end{array}$ & $\begin{array}{l}\text { Unlicensed } \\
\qquad(n=165)\end{array}$ & $\begin{array}{c}\text { All brokers } \\
(n=270)\end{array}$ \\
\hline $\begin{array}{l}\text { Ever given financial } \\
\text { support**}\end{array}$ & 76.2 & 59.4 & 65.9 \\
\hline $\begin{array}{l}\text { Ever helped a domestic } \\
\text { worker with disputes with } \\
\text { her employer }\end{array}$ & 60.2 & 60.9 & 60.6 \\
\hline $\begin{array}{l}\text { Ever helped a service } \\
\text { industry worker with dis- } \\
\text { putes with her employer }\end{array}$ & 70.9 & 49.1 & 57.6 \\
\hline
\end{tabular}

Differences between groups significant at ${ }^{*} p<0.05{ }^{* *} p<0.01{ }^{* * *} p<0.001$;

workers and bar maids, the latter being considered high risk for commercial sex work/commercial sexual exploitation. Overall, 7 percent of brokers admitted to placing girls in sex work: 4 percent of licensed brokers and 9 percent of unlicensed brokers.

\section{SUPPORT TO GIRLS AND YOUNG WOMEN}

In addition to job placements, a considerable proportion of brokers reported assistance to girls they placed (Table 5). Sixty-six percent of brokers reported ever having given financial support to girls (76 percent of licensed brokers versus 59 percent of unlicensed brokers; $p<0.01$ ). When asked about the number of girls helped in the last year, licensed brokers reported helping more girls, an average of 15 girls in the last year as opposed to an average of six girls among unlicensed brokers $(p<0.05)$. Sixty-one percent of brokers reported helping domestic workers in disputes with their employers with no significant differences between licensed and unlicensed brokers; and 58 percent report helping girls in the service

FIGURE 1: Type of assistance given by brokers to domestic workers (among those providing assistance) ( $\mathrm{n}=157)$

100

80

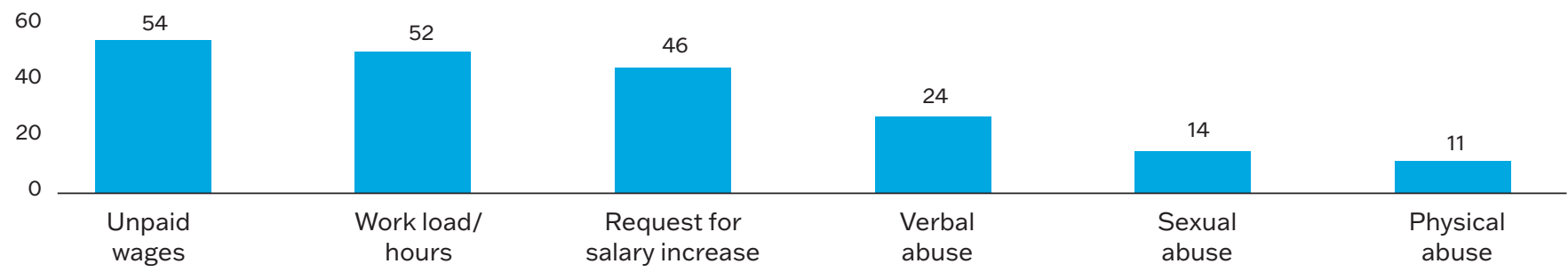

Type of assistance 
"Illegal brokers take advantage of us

without being taxed. They take them

(girls) from here, steal from them, rape

them, make them take drugs, and send

them back to us after all that. Then we

get blamed you see? Because the girls

don't understand that the illegal ones

are different from us."-Licensed broker

industry with employer disputes (71 percent of licensed brokers versus 49 percent of unlicensed brokers; $\mathrm{p}<0.01$.

Figure 1 shows the type of support and assistance given to domestic workers by brokers. Over half of the brokers who provided support to girls in domestic work offered assistance related to wages that were not paid by their employer or long working hours or heavy workloads. A considerable proportion of brokers intervened in the case of domestic abuse, sexual abuse, or physical abuse. Many brokers in the qualitative interviews described the assistance and support that they give to girls:

I also buy them food if they are hungry and if they don't have any money. I know how it is to be hungry. At least I can buy them shiro to share.-Licensed broker

I have helped two girls in court with rape cases in the last three years... [In one case] the wife of the employer left for a trip and he [employer] went straight to the worker's room and raped her. Then he denied he employed her. She gave the police my number and they called me. I confirmed that I got her employed there with all the documents I keep here, and he was taken to court.-Licensed broker

Many brokers, especially licensed ones, expressed satisfaction about helping migrant girls and young women. They described pleasure in seeing their clients succeed and make a good life for themselves:

They call me on phone and thank me-girls who I helped them to get jobs other than at the night club-they say their life would have been spoiled if they had worked with the other girls in the night club. But they are now in better positions and they thank me. They say that they have returned to their family. They have started their education. They call me and tell me these stories and I am happy when I hear this._Unlicensed broker
TABLE 6: Percent of brokers being aware of and engaging in abuse and exploitation of female clients, by licensing status

\begin{tabular}{|l|c|c|c|}
\hline & $\begin{array}{c}\text { Licensed } \\
(\mathrm{n}=105)\end{array}$ & $\begin{array}{c}\text { Unlicensed } \\
(\mathrm{n}=165)\end{array}$ & $\begin{array}{c}\text { All brokers } \\
(\mathrm{n}=270)\end{array}$ \\
\hline $\begin{array}{l}\text { Know of brokers who have } \\
\text { sex with girls they place** }\end{array}$ & 31.4 & 51.5 & 43.7 \\
\hline $\begin{array}{l}\text { Know of brokers who coerce } \\
\text { or trick girls into going into } \\
\text { sex work }\end{array}$ & 37.1 & 37.6 & 37.4 \\
\hline $\begin{array}{l}\text { Know of brokers who bring } \\
\text { girls from rural areas for sex } \\
\text { work }\end{array}$ & 27.6 & 36.0 & 32.7 \\
\hline $\begin{array}{l}\text { Had sex with a client in the } \\
\text { last two years*** }\end{array}$ & 10.5 & 30.1 & 22.4 \\
\hline Among brokers reporting sex with clients (n=60): & [24.5] & 25.0 \\
\hline \multicolumn{1}{|l|}{$\begin{array}{l}\text { Girl(s) did not want to } \\
\text { have sex }\end{array}$} & [27.3] & {$[46.9]$} & 43.3 \\
\hline \multicolumn{2}{l|}{$\begin{array}{l}\text { It was the girl(s) first } \\
\text { time having sex }\end{array}$} & [27.3] & \\
\hline
\end{tabular}

Differences between groups significant at ${ }^{*} p<0.05{ }^{* *} p<0.01{ }^{* * *} p<0.001$; Figures in brackets '[ ]' denote less than 60 cases

When you see that their future life is in better shape, it may feel like you helped them do that. For example, there was a girl who I know personally and who I assisted to be employed in the pool hall. Now, she has a better life. She opened her own pool hall and her own shop, and I know that such girls are really helping their families.-Unlicensed broker

\section{ABUSE AND EXPLOITATION}

Brokers were reportedly aware of other brokers who were abusive or exploitive of their female clients (Table 6). Overall, 44 percent of brokers know of other brokers who have sex with girls they place, with significantly more unlicensed brokers being aware of such brokers (52 percent) compared to licensed brokers (31 percent). Brokers also reported knowing of cases where girls are coerced or tricked into sex work or transported from rural areas for sex work.

When asked if they, themselves, have had sex with their female clients in the last two years, 22 percent affirmed that they have had sex with clients, with significantly more unlicensed brokers reporting sex compared to licensed brokers (unlicensed 30 percent; licensed 11 percent; $\mathrm{p}, 0.001)$. For a considerable percentage of girls, they reportedly did not want to have sex (25 percent) and it was their first time to have sex (43 percent). Brokers described ways in which their colleagues take advantage of girls:

When a girl comes, he [broker] can deceive her in order to do what he wants to her. He may stay with her during the night. He can say, "I am going to find you work in 
good place. I love you and I am going to marry you." But, after he get what he wants from her, and she stays for two or three days with him, he takes her out and makes her employed.-Unlicensed broker

In the case of some brokers who are unethical, what they do is that they book a room if they want and they make them stay there until they link her with the employer. They do various sexual offenses. I know that there are brokers who make them stay like this, and then take them to their employers after that. It is based on this that I say that there are brokers who are unethical.-Unlicensed broker

There are young brokers who are our friends... I would not call them friends, but colleagues. So, if these ones [brokers] get good looking girls, they never let them go. They take them to their home first and "taste" them-that's what they call it. This is common.-Licensed broker

\section{"GOOD" AND "BAD" BROKERS}

Brokers frequently characterized other brokers as either good or bad, or ethical or unethical. In particular, licensed brokers complained about the behavior of unlicensed brokers. They described them as being prone to unethical behavior, including tricking or coercing girls into sex work, getting them started on drugs and alcohol, placing girls in dangerous or exploitive positions, and prioritizing making money over the girls' safety and welfare. Unlicensed brokers were considered to give all brokers a bad name and some licensed brokers felt that their professional reputations were, at times, damaged because of the behavior of unlicensed brokers. Some described having to support girls who had been exploited and abused by other brokers:

Illegal brokers take advantage of us without being taxed. They take them (girls) from here, steal from them, rape them, make them take drugs, and send them back to us after all that. Then we get blamed you see? Because the girls don't understand that the illegal ones are different from us... If you see outside now, there are more than 30 of them. Around here are illegals (brokers) talking and taking drugschat (khat). They convince our customers and take them away. They sweet-talk the girls and tell them stories-if they are beautiful. Some of the girls leave their clothes here with me and get back to me after a month, after all the bad things she has been through with these guys. - Licensed broker
Many migrating girls lack understanding

of the risks that they may encounter

in the migration journey and unwisely

put their trust in strangers, such as

brokers, who may do them harm.

Additional initiatives are needed to make

girls aware of the potential pitfalls in

undertaking migration and encourage

them to make appropriate plans for

their safe travel and initial days in their

destination.

We can talk about bad employers and bad employees. As you mentioned, unmarried men harass girls, so we don't give them [domestic] workers. Well, there are those workers who steal things, so we don't get employment for these ones. There are also these brokers who just do it [brokerage] on the street... We have offices, you see. We can go nowhere. But the illegal brokers hide after they do something horrible. As for us, we have to follow the law. If it is the employer is the bad one here, we even sue them. Many times, they refuse to give the girls their salary. I have helped them get their money so many times... They [illegal brokers] do bad things to girls and hide somewhere in the slums. There are more than 15 of them just around here... One pays tax and money for rent, the other just sits under a tree and does it. This is not proper.-Licensed broker

One unlicensed broker described that there is little control over unlicensed brokers, citing that their clients are often decision makers and law enforcement themselves:

Nobody ever made me stop. Even, sometimes the police and other powerful people are the ones who contact me the most to provide them [with employees\}. Those who are in power and some police officers and administrators have the culture of hiring employees through brokers... In the case of government employees, most of the time they come to us in order not to pay 100 or 200 birr for the [licensed] broker... Therefore, as long as it is in their hands, they haven't affected me.-Unlicensed broker 
DISCUSSION AND

\section{RECOMMENDATIONS}

Brokers (or delalas) are a common work role in Ethiopia, with many sectors such having intermediaries who make connections between buyers and sellers or two different parties. Brokers are required to be licensed by the Ministry of Labour and Social Affairs, but many operate on an informal, unlicensed basis. Brokers for job placement are an important and, frequently, first point of contact for girls who migrate from rural areas. Upon arrival into the city, migrating young women frequently seek out available brokers to place them into jobs; they may have their phone number before departure, or are approached by brokers upon arrival. As such, arriving girls and young women who do not have other support systems in the city are highly dependent on brokers during their initial days in the city. Perhaps, for this reason, brokers are often located in the vicinity of bus stations, so that they can easily be located by arriving girls.

Brokers can provide support to girls that goes beyond job placement. They report providing girls with necessary help in their initial days, including financial assistance, short-term lodging, and food. Alternatively, brokers can be a source of considerable risk for girls. It was reported that brokers often exploit newly arriving girls for sex, expose them to drugs and alcohol, and place them into risky situations through deception and coercion-including sex work. Our research suggests that brokers who are unlicensed are more prone to these behaviors, while licensed brokers felt that such actions gave the profession a bad name.

\section{Based on findings from this descriptive research, we make specific recommendations for policymakers and programmers:}

\section{Programmatic support and attention to newly arriving migrant girls.}

Recent research highlights that girls who migrate experience heightened vulnerability upon arrival to their destinations, where they frequently lack jobs, a place to stay, support networks, and familiarity with the surroundings. ${ }^{6,7}$ Brokers are often their first point of contact in the city. Therefore, the intentions and actions of brokers have a profound impact on the trajectory of the girl and her safety and well-being. Brokers fulfill an important function in connecting them to employers and supporting them in navigating life in a city. Harnessing the capacity of brokers to increase and extend this support would potentially benefit girls on the move. This could include building their understanding and capacity on referral services, including shelters, and establishing affiliation and partnership with local bureaus of women, children, and youth affairs. Our research also showed that brokers need sensitization on gender issues and the capabilities of girls and young women.
Enforcement of licensing among brokers and enforcing code of conduct among brokers.

Our research suggested that brokers take advantage of girls, including through deception, abuse, and exploitation. There were some second-hand reports of broker behavior that would constitute trafficking. There were indications that unlicensed brokers are more likely to carry out harmful or illegal actions. Licensed brokers should be required to adhere to a code of conduct that promotes ethics in the profession, including adherence to labor laws and assurance of the safety and well-being of clients they support. Unlicensed brokers should be required to obtain a license and enforcement should be strengthened in this regard. Greater oversight of brokers is needed to ensure practitioners adhere to ethical standards in the profession. In addition, migrating populations need to understand the difference between licensed and unlicensed brokers and be encouraged to verify a broker's license.

\section{Education and awareness-raising for migrating girls}

Many girls and young women in Ethiopia migrate from rural areas during adolescence, often on their own and without any planning. ${ }^{8}$ Many migrating girls lack understanding of the risks that they may encounter in the migration journey and unwisely put their trust in strangers, such as brokers, who may do them harm. Additional initiatives are needed to make girls aware of the potential pitfalls in undertaking migration and encourage them to make appropriate plans for their safe travel and initial days in their destination. This could include proper planning to include prior linkage with trusted friends and relatives who can receive them and give them safe accommodation and better awareness of the potential for abuse and exploitation.

\section{NOTES}

1. Bundervoet, Tom. 2018. Internal Migration in Ethiopia: Evidence from a Quantitative and Qualitative Research Study. Washington DC: World Bank.

2. Wagaye Berhanu. "Of domestic help and their brokers," The Reporter 25 March 2017. Available at: https://www.thereporterethiopia.com/content/ domestic-help-and-their-brokers. [Accessed on October 28, 2019].

3. Girma W, Erulkar A, 2009. "Commercial sex workers in five Ethiopian cities: A baseline survey for targeted HIV prevention for most-at-risk populations," Addis Ababa: Population Council report, September.

4. Results from the study of migrant girls are found in: Erulkar A, Medhin G, Negeri L. 2017. "The Journey of Out-of-School Girls in Ethiopia: Examining Migration, Livelihoods and HIV," Addis Ababa: Population Council, August.

5. Data was collected in 2016. Therefore, the exchange rate prevailing in 2016 was used to estimate the US dollar equivalent.

6. Temin, Montgomery, Engebretsen, et. al. 2013. Girls on the Move: Adolescent Girls and Migration in the Developing World. New York: Population Council.

7. Erulkar, Girmay, Negeri, 2017. Op. cit.

8. Erulkar, Girmay, Negeri, ibid. 